\title{
Telomere-independent ageing in the longest-lived non-colonial animal, Arctica islandica
}

\author{
Heike Gruber ${ }^{\mathrm{a}, \mathrm{b}, *}$, Ralf Schaible $^{\mathrm{b}}$, Iain D. Ridgway ${ }^{\mathrm{b}, \mathrm{c}}$, Tracy T. Chow ${ }^{\mathrm{d}}$, Christoph Held ${ }^{\mathrm{e}}$, Eva E.R. Philipp ${ }^{\mathrm{a}}$ \\ a Institute of Clinical Molecular Biology, Christian-Albrechts-University Kiel, Germany \\ ${ }^{\mathrm{b}}$ Max Planck Institute for Demographic Research, Rostock, Germany \\ c School of Ocean Sciences, College of Natural Sciences, Bangor University, Menai Bridge, Anglesey, LL59 5AB, Wales, United Kingdom \\ d Department of Biochemistry and Biophysics, University of California, San Francisco, CA, USA \\ e Alfred Wegener Institute for Polar and Marine Research, Functional Ecology, Bremerhaven, Germany
}

\section{A R T I C L E I N F O}

\section{Article history:}

Received 18 September 2013

Received in revised form 19 December 2013

Accepted 25 December 2013

Available online 3 January 2014

Section Editor: T.E. Johnson

\section{Keywords:}

Telomere

Telomerase

Arctica islandica

Longevity

Maintenance

\begin{abstract}
A B S T R A C T
The shortening of telomeres as a causative factor in ageing is a widely discussed hypothesis in ageing research. The study of telomere length and its regenerating enzyme telomerase in the longest-lived non-colonial animal on earth, Arctica islandica, should inform whether the maintenance of telomere length plays a role in reaching the extreme maximum lifespan (MLSP) of $>500$ years in this species. Since longitudinal measurements on living animals cannot be achieved, a cross-sectional analysis of a short-lived (MLSP 40 years from the Baltic Sea) and a long-lived population (MLSP 226 years Northeast of Iceland) and in different tissues of young and old animals from the Irish Sea was performed. A high heterogeneity of telomere length was observed in investigated A. islandica over a wide age range (10-36 years for the Baltic Sea, 11-194 years for Irish Sea, 6-226 years for Iceland). Constant telomerase activity and telomere lengths were detected at any age and in different tissues; neither correlated with age or population habitat. Stable telomere maintenance might contribute to the long lifespan of A. islandica. Telomere dynamics are no explanation for the distinct MLSPs of the examined populations and thus the cause of it remains to be investigated.
\end{abstract}

(c) 2014 Elsevier Inc. All rights reserved.

\section{Introduction}

The bivalve Arctica islandica is the longest-lived non-colonial animal known to science. A. islandica can be found in the northern hemisphere and lives on continental shelves across the North Atlantic down to Virginia at the western Atlantic coast and to the Barents Sea in the east (Begum et al., 2009), where it can tolerate a wide range of different environmental factors (salinity, temperature, oxygen availability) (Basova et al., 2012). Their distribution into the Baltic Sea (BS) and the White Sea seems to be limited by ecological attributes of brackish environment like salinity, temperature, and oxygen gradients (Philipp et al., 2012). The oldest individual ever observed in this species was found Northeast of Iceland (IC) with an age of more than 500 years (Butler et al., 2013). The Irish Sea (IS) population has an estimated maximum lifespan (MLSP) of 220 years (Ridgway et al., 2012) and individuals of the BS population reach an age of approximately 40 years (Begum et al., 2010). Thus MLSP of this species varies extremely between

Abbreviations: MLSP, maximum lifespan; BS, Baltic Sea; IC, Iceland; IS, Irish Sea; LSG, line of strongest growth; PSU, practical salinity unit.

* Corresponding author. Tel.: +493812081 151.

E-mail addresses: h.gruber@ikmb.uni-kiel.de, hgruber@demogr.mpg.de (H. Gruber), schaible@demogr.mpg.de (R. Schaible), ridgway@demogr.mpg.de (I.D. Ridgway), tracy.Chow@ucsf.edu (T.T. Chow), christoph.held@awi.de (C. Held), e.philipp@ikmb.uni-kiel.de (E.E.R. Philipp). populations and seems to depend on the respective environmental conditions (Basova et al., 2012). The extreme difference in MLSP in A. islandica populations offers a promising opportunity for ageing research, such as the examination of the telomere dynamics with age.

In many species a loss of proliferative capacity of somatic cells can be observed during cellular ageing. Shortening of telomeres is discussed as one responsible factor for the replicative senescence of somatic cells, and is proposed to be one of the reasons why animals age and show an age-related increase of mortality (Wright and Shay, 2005). The telomere structure, consisting of DNA repeat sequences ( $5^{\prime}$-TTAGGG-3'), is highly conserved among vertebrates (Meyne et al., 1989) as well as among invertebrates (Traut et al., 2007). Cells approach senescence if telomere length reaches a certain threshold, the so-called Hayflick limit (Bolzán and Bianchi, 2006; Hayflick, 1965). The activation of the enzyme telomerase (Aubert and Lansdorp, 2008) or alternative telomere lengthening pathways (Bryan et al., 1997) can maintain telomere lengths, leading to theoretically unlimited proliferative potential. Hence, telomerase is expressed primarily in germ cells (Zalenskaya and Zalensky, 2002), stem cells (Mason, 2003) and in actively proliferating transit cells (Buchkovich and Greider, 1996). In normal human tissue telomerase is activated in early embryogenesis and during the first trimester, thereafter it is repressed in adult tissues, supposedly resulting from the relationship of active telomerase linked to cancer (Forsyth et al., 2002; Shay and Wright, 2011). 
Progressive telomere shortening is very often linked to tissue and organismal ageing (Campisi, 1996; Proctor and Kirkwood, 2002) or to a stressful environment (Metcalfe and Monaghan, 2003); and telomere maintenance has been shown to play a role in organismal longevity (Haussmann et al., 2005; Joeng et al., 2004). In contrast, an increase of telomere length with age has been observed in the extreme long-lived bird, the Leach's storm petrel, which reaches a MLSP of 36 years (Haussmann et al., 2003b). Similar results with such a positive relationship of telomere length and/or telomerase activity with age are observed in long-lived trees (Pinus longaeva, (Flanary and Kletetschka, 2005)), the sand lizard (Lacerta agilis, (Olsson et al., 2010)) and the water python (Liasis fuscus, (Ujvari and Madsen, 2009)). More intriguing examples are asexual and sexual planarian flatworms or colonial ascidians showing significantly different patterns in telomere maintenance and telomerase activities (Sköld et al., 2011; Tan et al., 2012). Other studies e.g. in humans, mice and birds found that the rate of telomere shortening depends on different life stages. Higher rates of telomere shortening were observed in earlier life stages or during development, whereas during adult life the rate stays nearly constant (Forsyth et al., 2002; Hall et al., 2004; Pauliny et al., 2006). Another interesting aspect regarding telomere dynamics and longevity is a high telomerase activity combined with low telomere attrition examined in tissues or organs of animals which grow throughout their entire life (indeterminate growth) even during adulthood. This applies to most fish, lobsters, molluscs, and other long-lived marine invertebrates (e.g. Estabrooks, 2007; Klapper et al., 1998a; Klapper et al., 1998b; Owen et al., 2007; Plohl et al., 2002; Sköld et al., 2011).

In A. islandica, the relationship of MLSP to growth rate or development is comparable, i.e. late onset of maturation, slow growth rate, with other well established long-lived model systems for ageing (e.g. primates, naked mole-rat) (Ridgway et al., 2011). Further, the species demonstrates indeterminate growth with very low growth rates compared to other bivalves (Begum et al., 2010; Strahl et al., 2007; Witbaard, 1996) and a constant rate of cell proliferation in many different tissues (Strahl and Abele, 2010). A. islandica is found in habitats with extremely different environmental conditions and populations exhibit large variations in maximum lifespans (Basova et al., 2012). Recent studies in marine bivalve molluscs have revealed an association between longevity and resistance to multiplex stressors (oxidative, genotoxic stress) as well as between longevity and proteostasis in several species including A. islandica (Treaster et al., 2013; Ungvari et al., 2013a; Ungvari et al., 2011; Ungvari et al., 2013b). Remarkably no enhaced antioxidant capacity or protein recycling was detected in A. islandica compared to shorter-lived species (Ungvari et al., 2011) but a higher ability to withstand stress factors in general was observed leading to the conclusion that retarded ageing may be the cause for stable antioxidants and not vice versa (Ridgway, 2012). A deeper understanding of telomere dynamics with respect to longevity and environmental influences in organisms may be gained by the investigation of the exceptionally long-lived bivalve, the ocean quahog. The BS population endures great fluctuations in temperature, salinity and oxygen availability (Begum et al., 2010), whereas abiotic conditions in the Northeast of Iceland are much more constant and stable (Basova et al., 2012). It is hypothesized this may greatly influence the animals' energy allocation to tissue maintenance, growth or reproduction but also the physiological response to different environmental stressors as recently reported for different A. islandica populations (Abele and Philipp, 2012; Basova et al., 2012; Philipp et al., 2012). The vast difference in MLSP and the environmental variables makes the two populations from the BS and IC with shortest (BS, MLSP 40 years) and longest (IC, MLSP $>500$ years) MLSP reported so far interesting objects for ageing studies, especially for the examination of telomere dynamics in A. islandica.

We therefore investigate two questions: (i) Is there a relationship between telomere length and/or telomerase activity with age in A. islandica? (ii) Is the large variation in maximum lifespan between populations a consequence of a significantly faster telomere shortening that may result from higher oxidative stress levels in less favourable environments, e.g. in the BS, leading to faster telomere shortening and subsequently a reduced lifespan?

Hence, telomere dynamics among $A$. islandica individuals of differing ages and tissues of the IC, BS and the IS population are examined. In order to analyze the relationship between telomere dynamics and age, cross-sectional-analyses are necessary because longitudinal observations in A. islandica are, due to its long lifespan and generation cycle, not possible.

\section{Material and methods}

\subsection{Sampling of Arctica islandica specimen}

A. islandica of the BS were sampled at the station "Süderfahrt" $\left(54^{\circ} 32,6 \mathrm{~N} \mathrm{10} 42,1 \mathrm{E}\right)$ in February 2010. In March 2010 IC animals

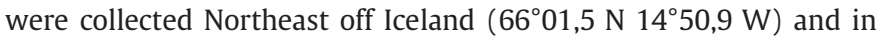
April 2010 IS animals were collected from the mouth of Belfast Lough $\left(54^{\circ} 42.10 \mathrm{~N}, 5^{\circ} 35.25 \mathrm{~W}\right)$. All populations were fished from 20 to $25 \mathrm{~m}$ water depth with a hydraulic rigid-toothed dredge and kept under stable aquarium conditions with flow through water from respective environments (BS: approx. $5^{\circ} \mathrm{C}$ and 20-25 PSU at the Geomar Helmholtz Centre for Ocean Research (Kiel, Germany), IC: approx. $5{ }^{\circ} \mathrm{C}$ and 35 PSU at the Suðurnes University Research Centre (Sandgerði, Iceland), IS: approx. $8{ }^{\circ} \mathrm{C}$ and $34 \mathrm{PSU}$ at the School of Ocean Sciences (Bangor, Wales)). After 5-7 days of recovery from sampling stress the animals were dissected. Gill, mantle, adductor muscle for all populations and foot, the heart, digestive gland for BS and IC only were sampled, shockfrozen in liquid nitrogen and stored at $-80{ }^{\circ} \mathrm{C}$ until further analysis.

\subsection{Age determination of animals}

A. islandica lay down annual growth rings in their shell (Schöne et al., 2005; Witbaard et al., 1994) from which the animals' individual ages can be deduced. The age determination was performed as described by Strahl et al. (2007) and Begum (2009). The right half of all shells was freed from organic remains with $13 \% \mathrm{NaOCl}$ (AppliChem, Germany) and the line of strongest growth (LSG) embedded in two component liquid metal glue (Toolkraft, Germany). A $1 \mathrm{~cm}$ wedge comprising the LSG was cut out with a diamond blade using an FKS/E bench saw (Proxxon, Germany). The wedge was then cut along the LSG with an IsoMet lowspeed saw (Buehler, USA). The LSG surface was sanded (with P400, P800, P1200; higher grits P2500, P4000 whenever necessary) and subsequently polished using $1 \mu \mathrm{m}$ MicroPolish II (Buehler-met, Germany). The age was determined by age ring counts directly under a microscope (Zeiss Imager Z.1) with a 2.5 magnification lens or on the PC monitor using an AxioCam HRc camera with the AxioVision software.

\subsection{Genomic analysis of DNA}

Genomic DNA from several populations (Kattegat, White Sea, Norway and Iceland) and tissues (foot, adductor muscle) were analysed to verify the conserved telomeric repeat 5'-TTAGGG-3' in this species. Collection of animals that were included in the preparation of the molecular libraries is described in detail in Begum et al. (2010). The DNA was extracted with the Qiagen DNeasy Blood and tissue protocol (Qiagen, Germany) using foot tissue (from Norway and from Iceland) or adductor muscle (from Kattegatt and from the White Sea). DNA concentration was determined with a Nanodrop ND-100 (Thermo Scientific) and $1.25 \mu \mathrm{g}$ of DNA from each specimen were pooled and sequenced on a Roche GS-FLX 454 sequencer (MacroGen, South Korea); for further details on preparation of the library see (Leese et al., 2012). The conserved telomere sequence 5'-TTAGGG-3' was blasted (blastn) (Altschul et al., 1990; Altschul et al., 1997) as repetitive sequence (30 repeats $=180 \mathrm{bp}$ ) against the genomic DNA sequence reads of $A$. islandica with a minimum eValue of $1 \mathrm{e}-003$. 


\subsection{Measurement of telomere length}

Mean terminal restriction fragment length (referred to as mean telomere length hereafter) was measured in gill tissue of 24 BS individuals and 38 IC animals across the respective total determined lifespan (10-36 years for BS, 6-226 years for IC animals) using the TeloTAGGG Telomere Length Assay (Roche, Germany) according to the protocol. DNA was extracted using DNeasy Blood\&Tissue Kit (Qiagen, Germany) according to the manufacturer's instruction. The DNA yield was determined using a NanoDrop ND-1000 Spectrophotometer (Peqlab Biotechnology $\mathrm{GmbH}$, Germany), $1 \mu \mathrm{g}$ of DNA was digested by restriction enzymes (Hinfl and RsaI) provided in the TeloTAGGG Telomere Length Assay over night at $37{ }^{\circ} \mathrm{C}$ in a heat block (Thermomixer compact, Eppendorf, Germany) and run on a $0.8 \%$ LE agarose (Biozym, Germany) gel at $30 \mathrm{~V}$ for $5 \mathrm{~h}$ in case of BS and IC animals. The gel was southern blotted onto a nylon Hybond-N + membrane (Amersham, USA) over night and the DNA fixed by baking the membrane at $80{ }^{\circ} \mathrm{C}$ for $2 \mathrm{~h}$. After hybridization and washing as described in the TeloTAGGG Telomere Length Assay manual, the southern blots were exposed to chemiluminescence for $20 \mathrm{~min}$ and analysed in a Molecular Imager ChemiDoc XRS Imaging System (BioRad, USA). Mean terminal restriction fragment lengths were detected as genomic DNA smears resolved in the gel and the area of highest density detected by the QuantityOne-4.6.8 software by BioRad was determined as the mean length of the telomeres (Fig. 1).

DNA extracted from gill, mantle and adductor muscle from 6 A. islandica individuals ( 3 young and 3 old) from the IS population was run on a $0.8 \%$ agarose gel in $0.5 x T B E$ at $60 \mathrm{~V}$ for $12 \mathrm{~h}$. Telomere lengths of this population were detected using a radioactive probe as described in Herbert et al. (2001).

\subsection{Measurement of telomerase activity}

Telomerase activity was measured using the Quantitative Telomerase Detection Kit (US Biomax Inc., USA) via realtime PCR. Enzyme activity was assessed in gill tissue of $10 \mathrm{BS}$ and 15 IC animals previously used for telomere length determination. For 3 of these individuals per population, telomerase was additionally measured in mantle, digestive gland, and foot to investigate tissue specific enzyme activity in tissues with different proliferation rates (Strahl and Abele, 2010). Protein extraction was performed according to the manufacturer's instructions, using $40 \mathrm{mg}$ ground tissue and 100-200 $\mu \mathrm{l}$ provided lysis buffer including the protease inhibitor cocktail (product no. 11836170001, Roche, Germany). The protein concentration was determined using the DC Protein Assay (BioRad, USA) according to the protocol, and measured at $612 \mathrm{~nm}$ wavelength in a Tecan GENios Pro plate reader (Tecan, Germany). Protein extracts were shock frozen in liquid nitrogen and stored at $-80{ }^{\circ} \mathrm{C}$ until further analysis. The Quantitative Telomerase Detection assay measures the telomerase activity from the extracted protein based on the enzyme's ability to add telomeric repeats on a substrate oligonucleotide. The elongated substrate is then amplified and quantified in a qRT-PCR. The initial concentration of telomerase can be inferred from the number of amplified qRT-PCR products using a standard curve generated with a provided standard template (TSR template). The volumes of the PCR-reaction were halved but to reduce pipetting errors, $1 \mu \mathrm{l}$ sample was added and the water content adjusted. Prior to qRT-PCR, samples were incubated at $25{ }^{\circ} \mathrm{C}$ for $20 \mathrm{~min}$ to allow telomerase mediated extension of provided primers with telomeric repeat ends. 40 PCR cycles were run as recommended in the manual. All samples were run in duplicates. Prior to sample measurements, a dilution series ranging from 0.044 to $2.1 \mu \mathrm{g} / \mu \mathrm{l}$ of protein extract from a mixed sample were run to identify the optimal protein concentration of $175 \mathrm{ng} / \mu \mathrm{l}$ for sample analysis. For positive controls HELA cellextracts and for negative controls heat inactivated $A$. islandica protein and heat inactivated HELA cell extracts were run to validate the method. For the calculation of telomerase activity in the samples, a TSR standard curve with the provided TSR control template was performed using $0.1 \mathrm{amol} / \mu \mathrm{l}$ (=60000 molecules), $0.02 \mathrm{amol} / \mu \mathrm{l}$ (=12000 molecules), $0.0008 \mathrm{amol} / \mu \mathrm{l}$ (=480 molecules), $0.000032 \mathrm{amol} / \mu \mathrm{l}$ (=20 molecules), and $0.0000064 \mathrm{amol} / \mu \mathrm{l}$ (=4 molecules).

\subsection{Statistics}

Data evaluation and further statistical analyses such as t-tests, Mann-Whitney test and calculation of nonparametric Spearman correlation were performed using GraphPad Prism 5 Version 5.04. Determination of outliers was undertaken using Grubb's test of GraphPad

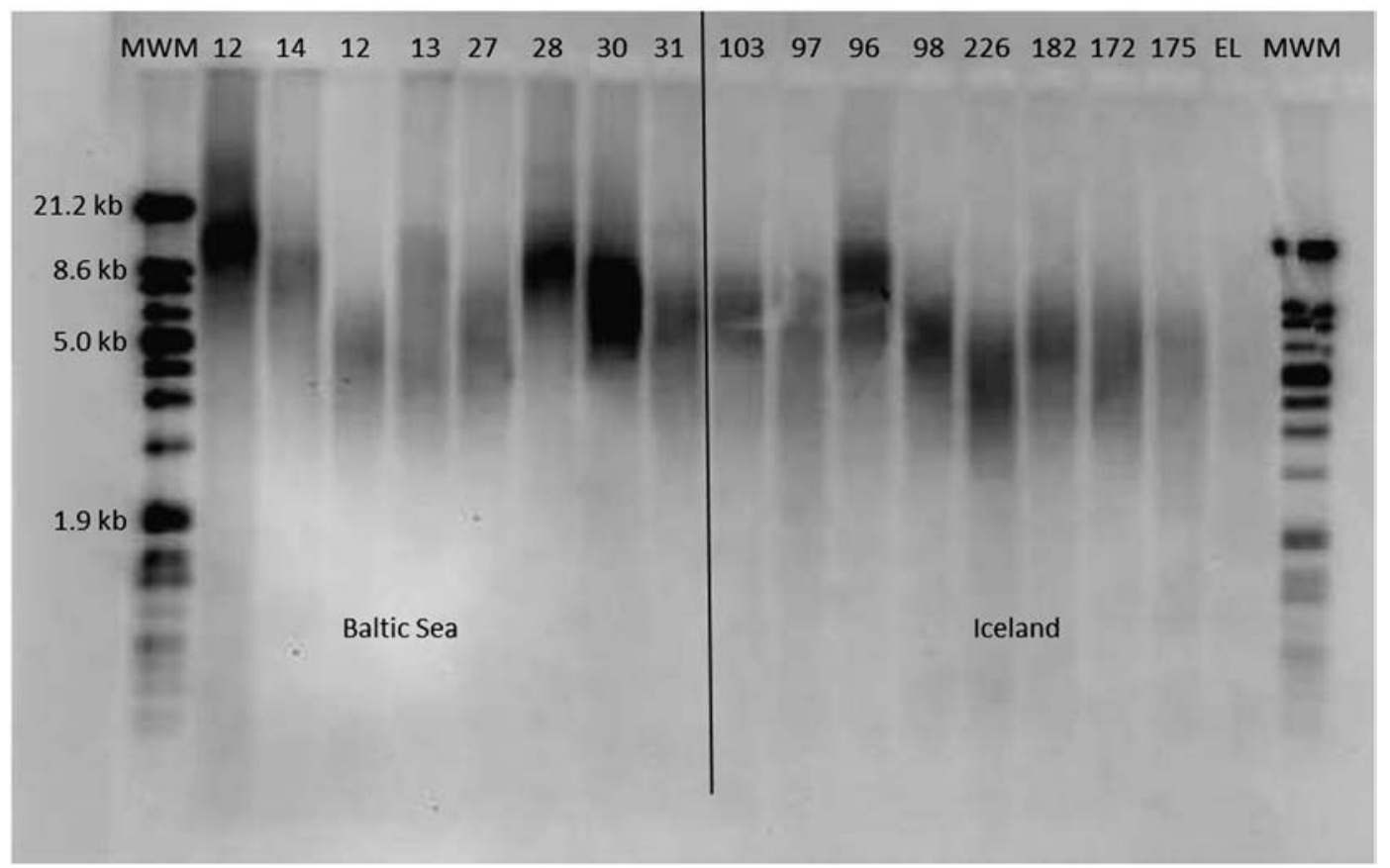

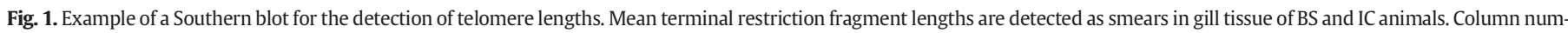
bers are ages in years of investigated animals. $\mathrm{MWM}=$ molecular weight marker, $\mathrm{EL}=$ empty lane. 
Table 1

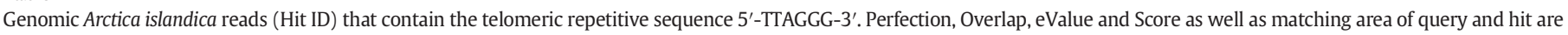
shown.

\begin{tabular}{|c|c|c|c|c|c|c|c|c|}
\hline Hit ID & Perfection & Overlap [bp] & eValue & Score & qStart & qEnd & hStart & hEnd \\
\hline GJ39D1101DR0VF & $93 \%$ & 123 & $1.00 \mathrm{E}-45$ & 180 & 58 & 180 & 425 & 303 \\
\hline GJ39D1101CMCPB & $92 \%$ & 77 & $6.00 \mathrm{E}-23$ & 105 & 103 & 179 & 315 & 239 \\
\hline GJ39D1101BDSS3 & $89 \%$ & 64 & $2.00 \mathrm{E}-10$ & 63.9 & 1 & 64 & 220 & 282 \\
\hline GJ39D1101ENZV3 & $89 \%$ & 64 & $2.00 \mathrm{E}-10$ & 63.9 & 37 & 100 & 220 & 282 \\
\hline GJ39D1101DMC7E & $87 \%$ & 64 & $5.00 \mathrm{E}-08$ & 56.0 & 114 & 177 & 215 & 153 \\
\hline GJ39D1101B8FSK & $88 \%$ & 59 & $2.00 \mathrm{E}-07$ & 54.0 & 119 & 177 & 288 & 231 \\
\hline GJ39D1101BMK7T & $88 \%$ & 53 & $1.00 \mathrm{E}-08$ & 58.0 & 18 & 70 & 11 & 63 \\
\hline GJ39D1101C39UO & $90 \%$ & 51 & $2.00 \mathrm{E}-07$ & 54.0 & 50 & 100 & 529 & 578 \\
\hline GJ39D1101BZGHQ & $100 \%$ & 36 & $9.00 \mathrm{E}-13$ & 71.9 & 129 & 164 & 36 & 1 \\
\hline GJ39D1101ENDY3 & $100 \%$ & 26 & $8.00 \mathrm{E}-07$ & 52.0 & 17 & 42 & 56 & 81 \\
\hline
\end{tabular}

Prism Software. GraphPad Prism 5 designates statistical significances as followed: $\mathrm{p} \leq 0.05\left(^{*}\right), \mathrm{p}<0.01\left(^{* *}\right), \mathrm{p}<0.001\left(^{* * *}\right), \mathrm{p}<0.0001\left(^{* * * *}\right)$. In column charts, data are expressed as means \pm SEM, unless otherwise indicated.

\section{Results}

\subsection{Genomic analysis of DNA sequences}

The BLAST search of the well conserved telomeric repeat sequence, 5'-TTAGGG-3', in genomic readout data of $A$. islandica from different populations and tissues revealed ten different reads (Table 1) containing the repetitive telomere sequence. An overlap of 26-123 bp with a perfection between 88 and 100\% was detected.

\subsection{Telomere length}

Mean telomere lengths were determined in gill tissue of 38 IC animals (age range 6-226 years), 24 BS animals (age range 10-36 years) and different tissues (gill, mantle, adductor muscle) of 6 IS animals (three young, 11 years and three old, $2 \times 135$ and 194 years) using the TeloTAGGG Telomere Length Assay (Roche, Germany). The Southern blot in Fig. 1 reveals age-independent mean telomere length, e.g. similar telomere lengths of 12 and 27 year old BS (sample lane 3 and 5) and 98 and 182 year old IC individuals (sample lane 12 and 14). Mean telomere length in gill tissue of the IC population ranged from 4.72 to $19.11 \mathrm{~kb}$, from 3.88 to $15.44 \mathrm{~kb}$ (Fig. 2) in the BS population and in investigated tissues of the IS population from 5.63 to $14.30 \mathrm{~kb}$ (Fig. 3). This indicates a high heterogeneity of mean telomere length in measured populations independent of individual age and tissues. Neither age (Figs. 2 and 3) nor size (data not shown) correlated with mean telomere length (nonparametric Spearman $\mathrm{rs}_{\mathrm{IC}}=-0.22$, $\mathrm{p}$-value $=$
$0.18 ; \mathrm{rs}_{\mathrm{BS}}=-0.08$, $\mathrm{p}$-value $=0.72$ ) in the IC or BS populations and ANOVA of IS animals revealed no significant differences between the age groups. In young as well as old animals short and long telomeres were detected (Figs. 2 and 3). Further, no significant differences in mean telomere length between individuals of IC, BS and IS of similar age or between different tissues within the IS population could be observed (mean of IC $=8.55 \mathrm{~kb}$, mean of $\mathrm{BS}=8.26 \mathrm{~kb}$, mean of IS $=7.73 \mathrm{~kb})$.

\subsection{Telomerase activity}

Telomerase activity was measured in gill tissue of the BS and IC populations across a wide age range ( $\mathrm{BS}=10-36$ years, $\mathrm{IC}=8-226$ years). Telomerase activity was detected in individuals of all ages in both populations with high variability (Fig. 4), showing that the enzyme stays active throughout the complete lifespan of the animals. Statistical analysis showed no correlation of age with telomerase activity (nonparametric Spearman $\mathrm{rs}_{\mathrm{IC}}=0.14$, p-value $=0.64 ; \mathrm{rs}_{\mathrm{BS}}=0.22$, $\mathrm{p}$-value $=$ $0.54)$. The enzyme activity of both populations at the same age was comparable. Since the same individuals were used for telomerase activity and telomere length analysis, results could be correlated but revealed no direct coherence between mean telomere length and telomerase activity (Fig. 5) (nonparametric Spearman $\mathrm{rS}_{\mathrm{IC}}=0.15$, $\mathrm{p}$-value $=0.60$; $\mathrm{rs}_{\mathrm{BS}}=-0.35$, $\mathrm{p}$-value $=0.33$ ).

Additionally, telomerase activity was tested in gill, mantle, digestive gland, and foot tissue which are known to have different proliferation rates (Strahl and Abele, 2010). Enzyme activity was measured in BS individuals aged 21, 22 and 36 years and IC animals aged 68, 69 and 98 years. In $83 \%$ of investigated animals, telomerase was most active in foot and in $80 \%$ the enzyme was least active in mantle tissue (Fig. 6). In both populations the enzyme shows the same activity trend in the different tissues.

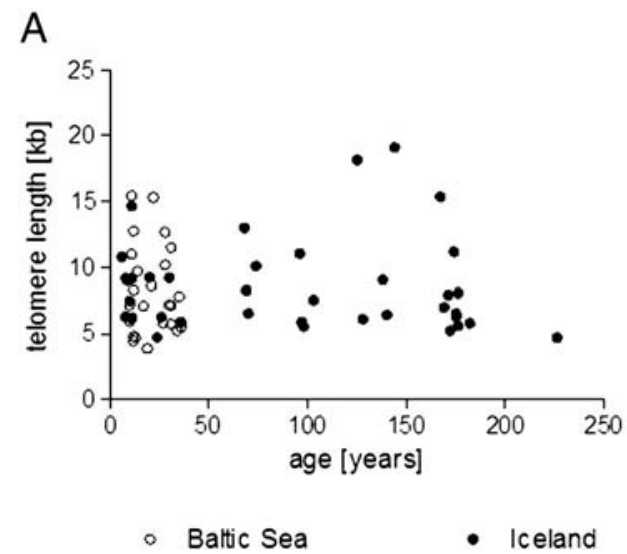

B

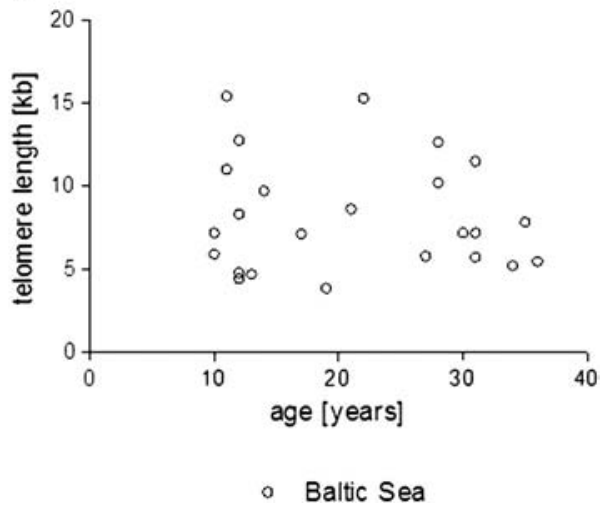

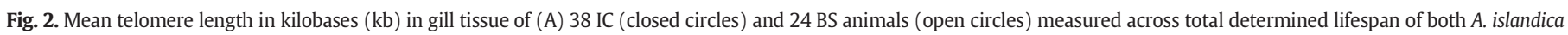
populations. (B) BS samples are separately shown for better overview. 


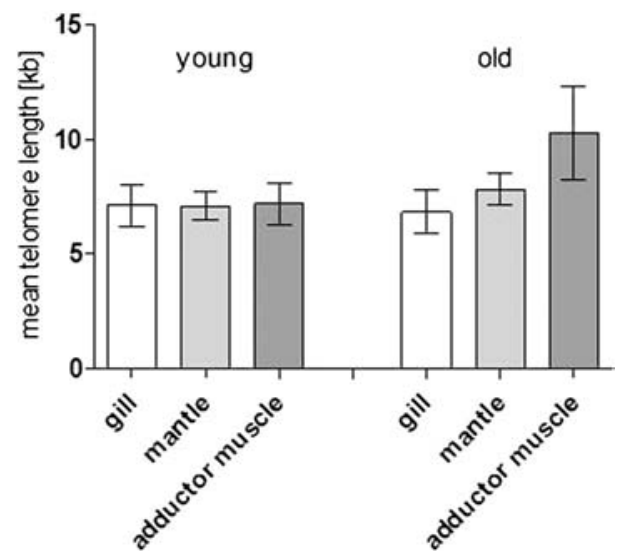

Fig. 3. Mean telomere length \pm SEM in kilobases (kb) in gill (open bars), mantle (light grey bars) and adductor muscle (dark grey bars) of three young (all 11 years) and three old $(2 \times 135$ and 194 years $)$ A. islandica from the IS.

\section{Discussion}

The well conserved telomeric repeat sequence $5^{\prime}$-TTAGGG-3' that can also be found on human chromosome ends, has previously been detected in marine bivalves such as the mussel (Mytilus galloprovincialis, (Plohl et al., 2002)), the bay scallop (Argopecten irradians, (Estabrooks, 2007)), the Pacific oyster (Crassostrea gigas, (Guo and Allen, 1997)) and other marine invertebrate species e.g. the sea urchin (Strongylocentrotus purpuratus, (Lejnine et al., 1995)) (Traut et al., 2007). However, as a first study we report this sequence in genomic DNA of several populations of the longest-lived non-colonial animal A. islandica. It is therefore eligible to measure telomere length using the TeloTAGGG Telomere Length Assay by Roche relying on this repeat sequence.

Individuals of the long-lived bivalve $A$. islandica, sampled at a wide range of ages, demonstrate the potential to maintain telomere length throughout their life. Mean telomere length was measured in gill tissue across all ages in the short-lived (investigated ages: 10-36 years) BS population, in the long-lived (investigated ages: 6-226 years) IC population as well as in three different tissues of young (11 years) and old ( $2 \times 135$ and 194 years) A. islandica from the IS. Thus, $90 \%$ and $88 \%$ of the BS MLSP ( 40 years) and the IS MLSP ( 220 years) respectively were covered. The individual with the highest MLSP ever observed was recovered Northeast of IC from deeper grounds ( $>80 \mathrm{~m}$ depth, at $66^{\circ} 31,59^{\prime} \mathrm{N} 18^{\circ} 11,74 \mathrm{~W}$ (Butler et al., 2013)) whereas the population investigated in the presented study was recovered from ca. $20 \mathrm{~m}$ depth from another bay Northeast of IC ( $66^{\circ} 01,5$ N $\left.14^{\circ} 50,9 \mathrm{~W}\right)$. Populations may be less disturbed at deeper grounds so that older individuals

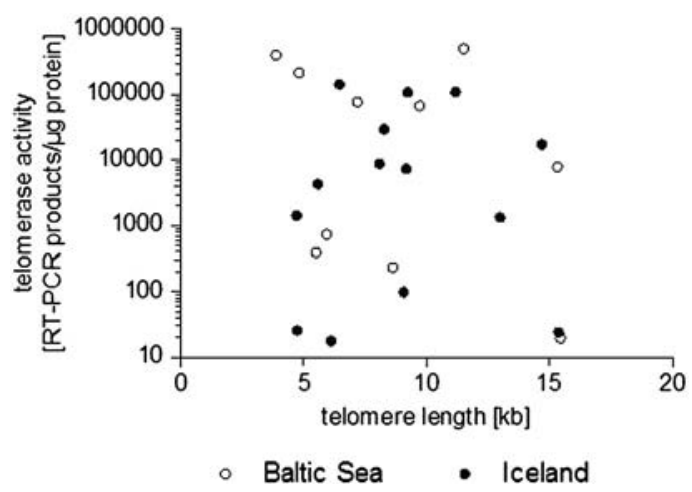

Fig. 5. Correlation of telomerase activity (in RT-PCR products/ $\mu$ g protein) with mean telomere length measured in gill tissue of the same individuals of IC (closed circles) and BS (open circles) population.

are more likely to be recovered from lower depths. We can assume that the studied population may reach a similar MLSP as reported for the population in Butler et al. (2013). However, the oldest individual in this study reached an age of 226 years, so that we consider this age as MLSP of this population. An overview of populations and studied ages are given in Table 2 demonstrating that telomere dynamics were studied in a high proportion of population-specific MLSPs.

The high heterogeneity of mean telomere length observed in A. islandica has also been reported in humans (Hewakapuge et al., 2008). The detected range of mean telomere length in A. islandica (3.88-19.11 kb) is comparable to those found in humans (3-17 kb) (Harley et al., 1990) and other species such as common terns (Sterna hirundo, (Haussmann et al., 2003a)) and the wedgeshall clam (Donax trunculus, (Plohl et al., 2002)). The maintenance of telomere length over age in $A$. islandica might be achieved by the activity of the enzyme telomerase found at all ages which did not change significantly over age. This could represent a prerequisite to prevent senescence and postpone mortality. Remarkably, the high variability in mean telomere length and telomerase activity at all ages between and within the BS and IC population could be observed leading to the conclusion that the high variation in telomere dynamics in the different age classes of $A$. islandica may be due either to external influences or individual properties.

Telomere dynamics have been widely studied as a proxy of cellular and organism senescence in relation to survival and lifespan (Haussmann and Marchetto, 2010; Horn et al., 2010). Telomere dynamics with age can show a large number of varieties: The classical pattern is that telomere length declines with age as observed in some animal species and also human (Aubert and Lansdorp, 2008; Harley et al., 1990); Zebra finch, (Haussmann and Vleck, 2002); and Great
A

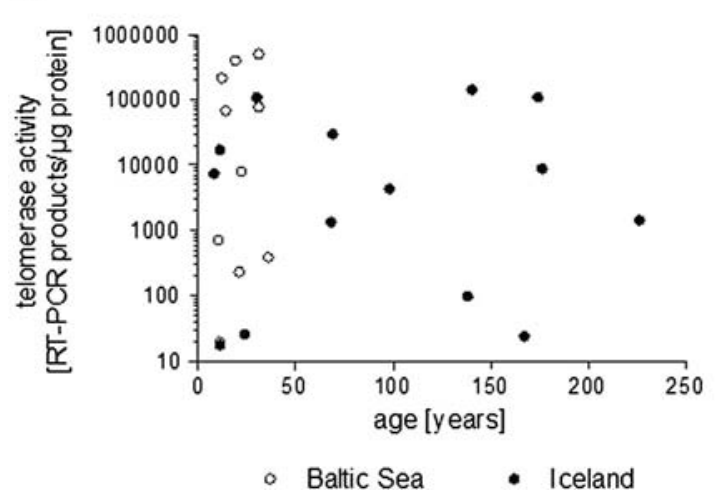

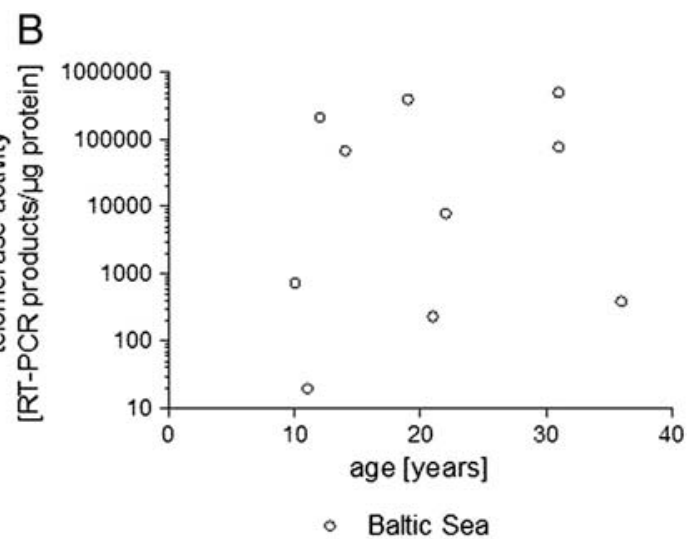

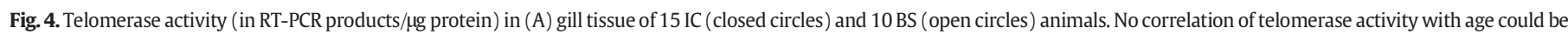
observed. (B) BS samples are separately shown for better overview. 


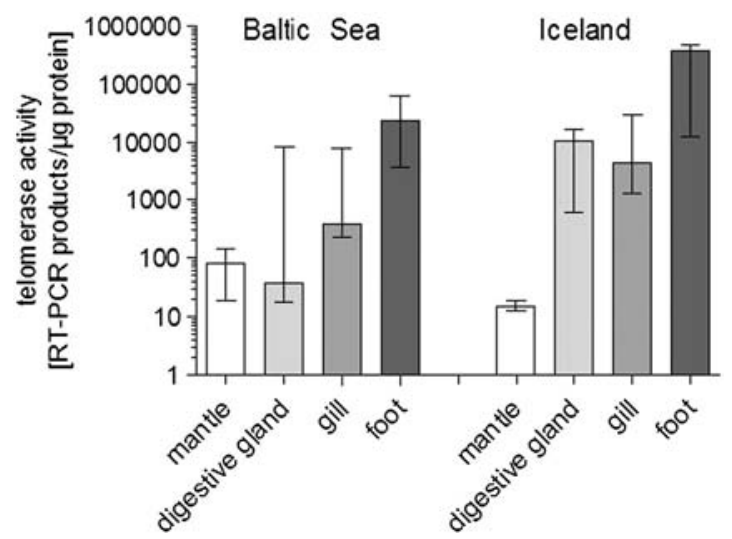

Fig. 6. Mean telomerase activity \pm SEM in RT-PCR products/ $\mu$ g protein in mantle (open bars), digestive gland (light grey bars), gill (dark grey bars) and foot tissue (black bars) of the BS and IC population ( $\mathrm{n}=3$ individuals per tissue). In mantle tissue of the BS population telomerase activity of only two individuals was measured.

frigatebird, (Juola et al., 2006). However, shortening of telomeres does not occur at a constant rate with age (Horn et al., 2010). A second pattern, contradictory to the first, shows increasing telomere length with advancing age as found in the bristlecone pine, ( $P$. longaeva, (Flanary and Kletetschka, 2005)), sand lizards (L. agilis, (Olsson et al., 2010)), and the water python (L. fuscus, (Ujvari and Madsen, 2009)). A third pattern describes no age-related telomere shortening in adulthood but a strong and often rapid shortening earlier in life, as observed in birds, the European shag and the wandering albatross (Hall et al., 2004; Pauliny et al., 2006). For $A$. islandica we document no change with age along the range of ages investigated (BS: 10-36 years, IS: 11-194 years, IC: 6-226 years) supporting several studies (Abele et al., 2008; Strahl et al., 2007; Ungvari et al., 2011) that found stable physical parameters in the ocean quahog over age which implies a lack of ageing in this species. Indeed the dynamics of both telomere length and telomerase activity in $A$. islandica seem to be stable and similar across all ages. Due to the chosen sampling pattern we have no information about telomere length during earlier growth stages of individuals younger than 6 years from the IC, 10 years from the BS and 11 years from the IS population. Telomerase expression of the sand scallop, Euvola ziczac, however has been detected in adult tissue (adductor muscle, gill, mantle, and male and female gonads) as well as during early developmental stages (Owen et al., 2007). The results of $A$. islandica are in line with other animals showing indeterminate growth, such as the rainbow trout, lobsters, molluscs, or other marine invertebrates, which express telomerase in all examined tissues during their complete investigated lifespan (Klapper et al., 1998b; Owen et al., 2007). As an emerging model system for ageing studies, bivalves, and especially the ocean quahog, can also compete with established longlived model systems for ageing such as primates and the naked molerat (Austad, 2010; Fischer and Steven, 2011; Lewis et al., 2012) that show similar life history associations between MLSP and growth rate or development (i.e. late onset of maturation, slow growth rate) (Ridgway et al., 2011). These findings imply that $A$. islandica does not merely attain exceptional longevity through low metabolic rate but also possesses similar traits to long-lived animals of other taxa.
Surprisingly, A. islandica from IC showed no specific strategy according to the telomere dynamics as compared to the BS individuals which is remarkable in light of the 10 -fold difference in maximum lifespan between the two populations (BS: MLSP 40 years, IC: MLSP > 500 years). As mentioned above, however, no sign of ageing has been found in this species and the short lifespan of A. islandica in the BS may rather be attributed to poor shell formation in a low salinity environment (Begum et al., 2010; Hiebenthal et al., 2012). Moreover, compared to the highly stable marine IC habitat the brackish BS environment is highly fluctuating not only in respect to salinity but also in ionic compositions of the water body, water temperature, oxygen content and nutrient concentrations which implies a general more stressful habitat and an impact on telomere dynamics as hypothesized by others (Hall et al., 2004; Horn et al., 2008; Jennings et al., 2000). Philipp et al. (2012) for example could show that $A$. islandica from the Baltic Sea and Iceland were found to differ in transcriptional response towards hypoxia which was attributed to the adaptation to different environmental stability of the two populations. Stressful environments have been linked to higher levels of oxidative stress, associated to telomere shortening (Jennings et al., 2000; Von Zglinicki, 2002). However, no correlation between telomere length and telomerase activity with age in either population of A. islandica indicates that the maintenance of telomere length is independent of environmental conditions in this species. Several telomereindependent functions of telomerase e.g. protection of mitochondria, inhibition of apoptosis, enhancement of DNA repair, promotion of cell growth and stem cell proliferation (reviewed in Bollmann (2008)) might influence enzyme activity and are important for the individual's fitness in their respective environment. A sustained expression of telomerase observed in $A$. islandica could hence also contribute to telomere-independent functions of telomerase.

We detected telomerase throughout all ages but also in different tissues (gill, mantle, digestive gland, foot), with lowest activity in mantle and highest in foot in the BS and IC population (Fig. 6). Telomerase activity in diverse tissues of several marine organisms with indeterminable growth has already been reported previously (Klapper et al., 1998a; Klapper et al., 1998b; Owen et al., 2007). Belair et al. (1997) demonstrated telomerase activity serves as a marker for cell proliferation in human tumours and normal cells, thus high telomerase activity is expected in highly proliferative tissue. According to Strahl and Abele (2010) mantle and gill tissue of IC A. islandica show similar proliferation rates whereas in animals from the German Bight proliferation rates were higher in gills compared to mantle tissue. Proliferation conditions in the different tissues in A. islandica are therefore not resolved and it is unclear whether the higher telomerase activity in gill compared to mantle tissue in the present study reflects higher proliferation rates in gill tissue. Foot tissue was not measured by Strahl and Abele (2010), thus there is no information about proliferation activity which could be correlated with the higher telomerase activity found in this tissue compared to all other investigated tissues. Personal observations (E.E.R. Philipp), however, noted a reduction in foot size after 16 days of exposure of $A$. islandica to hypoxia. We hypothesize the foot may serve as glycogen storage tissue accessed during periods of anaerobiosis (Oeschger, 1990), and is diminished after debilitating conditions. As this species is regularly exposed to hypoxia/anoxia, self-induced or by the environment (Philipp et al., 2012), high proliferation rates in the foot might therefore be a prerequisite for fast utilization and recuperation of the glycogen storage.

Table 2

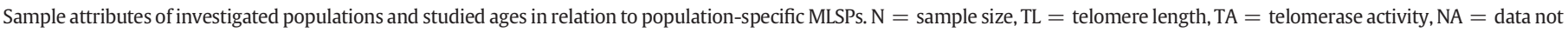
available.

\begin{tabular}{|c|c|c|c|c|c|c|}
\hline Population & $\begin{array}{l}\mathrm{N} \\
\mathrm{TL} / \mathrm{TA}\end{array}$ & $\begin{array}{l}\text { Size-range } \\
{[\mathrm{mm}]}\end{array}$ & $\begin{array}{l}\text { MLSP } \\
\text { [years] }\end{array}$ & $\begin{array}{l}\text { Investigated } \\
\text { ages [years] }\end{array}$ & $\begin{array}{l}\text { Investigated mean age } \\
\text { for TL/TA [years] }\end{array}$ & $\begin{array}{l}\text { Age-range } \\
\text { of MLSP covered }\end{array}$ \\
\hline Baltic Sea & $24 / 10$ & $33.16-60.6$ & 40 & $10-36$ & $17.7 / 20.7$ & $65 \%$ \\
\hline Irish Sea & 6/NA & $56.3-143.0$ & 220 & $11,135,194$ & 81.0/NA & $83 \%$ \\
\hline Iceland & $38 / 15$ & 22.11-105.02 & 226 & $6-226$ & $83.6 / 101.5$ & $97 \%$ \\
\hline
\end{tabular}


A possible selective mortality of individuals with shorter telomeres (Haussmann and Mauck, 2008) restricts cross-sectional-analyses in their conclusion about telomere shortening and telomerase activity over age and life stages. Another factor that cannot be examined in cross-sectional studies is environmental stressors which may have significant impacts on the rate of the telomere dynamics on both individual and population levels (Hall et al., 2004; Horn et al., 2008, 2010; Von Zglinicki, 2002).

\subsection{Summary and conclusion}

As emerging model systems, bivalves exhibit similar life history and developmental traits (Ridgway et al., 2011) compared to other model systems such as primates and the naked mole-rat (Fischer and Steven, 2011; Lewis et al., 2012). Especially the longest-lived noncolonial animal known to science, the bivalve $A$. islandica, shows a general lack of signs of ageing (Abele et al., 2008; Strahl et al., 2007; Ungvari et al., 2011). Supporting these findings, our study is the first presenting a lack of ageing-associated telomere dynamics in the ocean quahog. We document the well conserved telomeric repeat sequence 5'-TTAG GG-3' in several populations of A. islandica. We further demonstrate highly variable mean telomere length and telomerase activity which is continually expressed in different tissues throughout the lifespan in the longest- and shortest-lived populations of $A$. islandica. The correlation of telomerase activity with age, size and tissue was investigated as well as the correlation of telomerelength with telomerase activity. Apparently, A. islandica is extremely successful at maintaining cellular proliferation showing a lack of age-associated telomere shortening accompanied by a continuous telomerase activity throughout its lifespan. Equal telomere dynamics investigated in A. islandica populations with extremely different MLSPs indicate that MLSP is not determined by telomere length or telomerase activity so that the causative factor of this exceptional longevity remains to be investigated.

\section{Conflict of interest}

The authors have no conflicts of interests.

\section{Acknowledgements}

We thank Prof. Philip Rosenstiel, Director of the Institute of Clinical Molecular Biology in Kiel where this work was conducted, for his support. Correspondence concerning this research article should be addressed to H. Gruber (hgruber@demogr.mpg.de).

\section{References}

Abele, D., Philipp, E., 2012. Environmental control and control of the environment: the basis of longevity in bivalves. Gerontology 59, 261-266.

Abele, D., Strahl, J., Brey, T., Philipp, E.E.R., 2008. Imperceptible senescence: ageing in the ocean quahog Arctica islandica. Free Radic. Res. 42, 474-480.

Altschul, S.F., Gish, W., Miller, W., Myers, E.W., Lipman, D.J., 1990. Basic local alignment search tool. J. Mol. Biol. 215, 403-410.

Altschul, S.F., Madden, T.L., Schäffer, A.A., Zhang, J., Zhang, Z., Miller, W., Lipman, D.J., 1997. Gapped BLAST and PSI-BLAST: a new generation of protein database search programs. Nucleic Acids Res. 25, 3389-3402.

Aubert, G., Lansdorp, P.M., 2008. Telomeres and aging. Physiol. Rev. 88, 557-579.

Austad, S.N., 2010. Cats, "rats", and bats: the comparative biology of aging in the 21st century. Integr. Comp. Biol. 1-10.

Basova, L., Begum, S., Strahl, J., Sukhotin, A., Brey, T., Philipp, E., Abele, D., 2012. Age dependent patterns of antioxidants in Arctica islandica from six regionally separate populations with different life spans. Aquat. Biol. 14, 141-152.

Begum, S., 2009. Environmental Constraints on Growth, Age and Lifetime Metabolic Budgets of the Bivalve Arctica islandica. (PhD Thesis) Universität Bremen.

Begum, S., Basova, L., Heilmayer, O., Philipp, E.E., Abele, D., Brey, T., 2010. Growth and energy budget models of the bivalve Arctica islandica at six different sites in the Northeast Atlantic realm. J. Shellfish Res. 29, 107-115.

Begum, S., Basova, L., Strahl, J., Sukhotin, A., Heilmayer, O., Philipp, E., Brey, T., Abele, D., 2009. A metabolic model for the ocean quahog Arctica islandica - effects of animal mass and age, temperature, salinity, and geography on respiration rate. J. Shellfish Res. 28, 533-539.
Belair, C.D., Yeager, T.R., Lopez, P.M., Reznikoff, C.A., 1997. Telomerase activity: a biomarker of cell proliferation, not malignant transformation. Proc. Natl. Acad. Sci. 94, 13677-13682

Bollmann, F.M., 2008. The many faces of telomerase: emerging extratelomeric effects. BioEssays 30, 728-732.

Bolzán, A.D., Bianchi, M.S., 2006. Telomeres, interstitial telomeric repeat sequences, and chromosomal aberrations. Mutat. Res. Rev. Mutat. Res. 612, 189-214.

Bryan, T.M., Englezou, A., Dalla-Pozza, L., Dunham, M.A., Reddel, R.R., 1997. Evidence for an alternative mechanism for maintaining telomere length in human tumors and tumor-derived cell lines. Nat. Med. 3, 1271-1274.

Buchkovich, K.J., Greider, C.W., 1996. Telomerase regulation during entry into the cell cycle in normal human T cells. Mol. Biol. Cell 7, 1443-1454.

Butler, P.G., Wanamaker Jr., A.D., Scourse, J.D., Richardson, C.A., Reynolds, D.J., 2013. Variability of marine climate on the North Icelandic Shelf in a 1357-year proxy archive based on growth increments in the bivalve Arctica islandica. Palaeogeogr. Palaeoclimatol. Palaeoecol. 373, 141-151.

Campisi, J., 1996. Replicative Senescence: An Old Lives' Tale? Cell Press, Cambridge, MA ETATS-UNIS.

Estabrooks, S.L., 2007. The possible role of telomeres in the short life span of the bay scallop, Argopecten irradians irradians (Lamarck 1819). J. Shellish Res. 26, 307-313.

Fischer, K.E.A., Steven, N., 2011. The development of small primate models for aging research. ILAR J. 78-88.

Flanary, B.E., Kletetschka, G., 2005. Analysis of telomere length and telomerase activity in tree species of various life-spans, and with age in the bristlecone pine Pinus longaeva. Biogerontology 6, 101-111.

Forsyth, N.R., Wright, W.E., Shay, J.W., 2002. Telomerase and differentiation in multicellular organisms: turn it off, turn it on, and turn it off again. Differentiation 69, 188-197.

Guo, X., Allen Jr., S.K., 1997. Fluorescence in situ hybridization of vertebrate telomere sequence to chromosome ends of the Pacific oyster. Crassostrea gigas Thunberg. J. Shellfish Res. 16, 87-90.

Hall, M.E., Nasir, L., Daunt, F., Gault, E.A., Croxall, J.P., Wanless, S., Monaghan, P., 2004. Telomere loss in relation to age and early environment in long-lived birds. Proc. R. Soc. Lond. B Biol. Sci. 271, 1571-1576.

Harley, C.B., Futcher, A.B., Greider, C.W., 1990. Telomeres shorten during ageing of human fibroblasts. Nature 345, 458-460.

Haussmann, M.F., Marchetto, N.M., 2010. Telomeres: linking stress and survival, ecology and evolution. Curr. Zool. 56, 714-727.

Haussmann, M.F., Mauck, R.A., 2008. Telomeres and longevity: testing an evolutionary hypothesis. Mol. Biol. Evol. 25, 220-228.

Haussmann, M.F., Vleck, C.M., 2002. Telomere length provides a new technique for aging animals. Oecologia 130, 325-328.

Haussmann, M.F. Vleck, C.M., Nisbet, I.C., 2003a. Calibrating the telomere clock in common terns, Sterna hirundo. Exp. Gerontol. 38, 787-789.

Haussmann, M.F., Winkler, D.W., O'Reilly, K.M., Huntington, C.E., Nisbet, I.C.T., Vleck, C.M., 2003b. Telomeres shorten more slowly in long-lived birds and mammals than in short-lived ones. Proceedings of the Royal Society of London. Ser. B: Biol. Sci. 270, 1387-1392.

Haussmann, M.F., Winkler, D.W., Vleck, C.M., 2005. Longer telomeres associated with higher survival in birds. Biol. Lett. 1, 212-214.

Hayflick, L., 1965. The limited in vitro lifetime of human diploid cell strains. Exp. Cell Res. 37, 614-636.

Herbert, B.-S., Shay, J.W., Wright, W.E., 2001. Analysis of Telomeres and Telomerase, Current Protocols in Cell Biology. John Wiley \& Sons Inc.

Hewakapuge, S., van Oorschot, R.A., Lewandowski, P., Baindur-Hudson, S., 2008. Investigation of telomere lengths measurement by quantitative real-time PCR to predict age. Leg. Med. 10, 236-242.

Hiebenthal, C., Philipp, E.E.R., Eisenhauer, A., Wahl, M., 2012. Interactive effects of temperature and salinity on shell formation and general condition in Baltic Sea Mytilus edulis and Arctica islandica. Aquat. Biol. 14, 289-298.

Horn, T., Gemmell, N., Robertson, B., Bridges, C., 2008. Telomere length change in European sea bass (Dicentrarchus labrax). Aust. J. Zool. 56, 207-210.

Horn, T., Robertson, B., Gemmell, N., 2010. The use of telomere length in ecology and evolutionary biology. Heredity 105, 497-506.

Jennings, B.J., Ozanne, S.E., Hales, C.N., 2000. Nutrition, oxidative damage, telomere shortening, and cellular senescence: individual or connected agents of aging? Mol. Genet Metab. 71, 32-42.

Joeng, K.S.S., Joo, Eun, Lee, Kong-Joo, Lee, Junho, 2004. Long lifespan in worms with long telomeric DNA. Nat. Genet. 36, 607-611.

Juola, F.A., Haussmann, M.F., Dearborn, D.C., Vleck, C.M., Burger, A., 2006. Telomere shortening in a long-lived marine bird: cross-sectional analysis and test of an aging tool. Auk 123, 775-783.

Klapper, W., Heidorn, K., Kühne, K., Parwaresch, R., Krupp, G., 1998a. Telomerase activity in immortal fish. FEBS Lett. 434, 409-412.

Klapper, W., Kühne, K., Singh, K.K., Heidorn, K., Parwaresch, R., Krupp, G., 1998b. Longevity of lobsters is linked to ubiquitous telomerase expression. FEBS Lett. 439, $143-146$.

Leese, F., Brand, P., Rozenberg, A., Mayer, C., Agrawal, S., Dambach, J., Dietz, L., Doemel, J.S Goodall-Copstake, W.P., Held, C., 2012. Exploring Pandora's box: potential and pitfalls of low coverage genome surveys for evolutionary biology. PloS one 7, e49202.

Lejnine, S., Makarov, V.L., Langmore, J.P., 1995. Conserved nucleoprotein structure at the ends of vertebrate and invertebrate chromosomes. Proc. Natl. Acad. Sci. U. S. A. 92 2393-2397.

Lewis, K.N., Mele, J., Hornsby, P.J., Buffenstein, R., 2012. Stress resistance in the naked mole-rat: the bare essentials - a mini-review. Gerontology. http://dx.doi.org/ 10.1159/000335966. 
Mason, P.J., 2003. Stem cells, telomerase and dyskeratosis congenita. BioEssays 25, 126-133. Metcalfe, N.B., Monaghan, P., 2003. Growth versus lifespan: perspectives from evolutionary ecology. Exp. Gerontol. 38, 935-940.

Meyne, J., Ratliff, R.L., Moyzis, R.K., 1989. Conservation of the human telomere sequence (TTAGGG)n among vertebrates. Proc. Natl. Acad. Sci. 86, 7049-7053.

Oeschger, R., 1990. Long-term anaerobiosis in sublittoral marine-invertebrates from the Western Baltic Sea-Halicryptus-spinulosus (Priapulida), Astarte-borealis and Arcticaislandica (Bivalvia). Mar. Ecol. Prog. Ser. 59, 133-143.

Olsson, M., Pauliny, A., Wapstra, E., Blomqvist, D., 2010. Proximate determinants of telomere length in sand lizards (Lacerta agilis). Biol. Lett. 6, 651-653.

Owen, R., Sarkis, S., Bodnar, A., 2007. Developmental pattern of telomerase expression in the sand scallop, Euvola ziczac. Invertebr. Biol. 126, 40-45.

Pauliny, A., Wagner, R.H., Augustin, J., Szép, T., Blomqvist, D., 2006. Age-independent telomere length predicts fitness in two bird species. Mol. Ecol. 15, 1681-1687.

Philipp, E.E., Wessels, W., Gruber, H., Strahl, J., Wagner, A.E., Ernst, I.M., Rimbach, G. Kraemer, L., Schreiber, S., Abele, D., 2012. Gene expression and physiological changes of different populations of the long-lived bivalve Arctica islandica under low oxygen conditions. PLoS One 7, e44621.

Plohl, M., Prats, E., Martínez-Lage, A., González-Tizón, A., Méndez, J., Cornudella, L., 2002. Telomeric localization of the vertebrate-type hexamer repeat,(TTAGGG) $n$, in the wedgeshell clam Donax trunculus and other marine invertebrate genomes. J. Biol. Chem. 277, 19839-19846.

Proctor, C.J., Kirkwood, T.B.L., 2002. Modelling telomere shortening and the role of oxidative stress. Mech. Ageing Dev. 123, 351-363.

Ridgway, I.D., 2012. Comments on 'The biology and functional morphology of Arctica islandica' by Brian Morton, marine biology research, 2011. Mar. Biol. Res. 8, 95-97.

Ridgway, I.D., Richardson, C.A., Scourse, J.D., Butler, P.G., Reynolds, D.J., 2012. The population structure and biology of the ocean quahog, Arctica islandica, in Belfast Lough, Northern Ireland. J. Mar. Biol. Assoc. U. K. 92, 539-546.

Ridgway, I.D., Richardson, C.A., Austad, S.N., 2011. Maximum shell size, growth rate, and maturation age correlate with longevity in bivalve molluscs. J. Gerontol. A Biol. Sci. Med. Sci. 66A, 183-190.

Schöne, B.R.F., Jens, Pfeiffer, Miriam, Gleh, Renald, Hickson, Jonathan, Johnson, Andrew, L.A., Dreyer, Wolfgang, Oschmann, Wolfgang, 2005. Climate records from a bivalved Methuselah (Arctica islandica, Mollusca; Iceland). Palaeogeogr. Palaeoclimatol. Palaeoecol. 228, 130-148.

Shay, J.W., Wright, W.E., 2011. Role of telomeres and telomerase in cancer, Semin. Cancer Biol.Elsevier 349-353.

Sköld, H.N., Asplund, M.E., Wood, C.A., Bishop, J.D., 2011. Telomerase deficiency in a colonial ascidian after prolonged asexual propagation. J. Exp. Zool. 316, 276-283.
Strahl, J., Abele, D., 2010. Cell turnover in tissues of the long-lived ocean quahog Arctica islandica and the short-lived scallop Aequipecten opercularis. Mar. Biol. 157, 1283-1292.

Strahl, J., Philipp, E., Brey, T., Broeg, K., Abele, D., 2007. Physiological aging in the Icelandic population of the ocean quahog Arctica islandica. Aquat. Biol. 1, 77-83.

Tan, T.C., Rahman, R., Jaber-Hijazi, F., Felix, D.A., Chen, C., Louis, E.J., Aboobaker, A., 2012. Telomere maintenance and telomerase activity are differentially regulated in asexual and sexual worms. Proc. Natl. Acad. Sci. U. S. A. 109, 4209-4214.

Traut, W., Szczepanowski, M., Vítkova, M., Opitz, C., Marec, F., Zrzavy, J., 2007. The telomere repeat motif of basal metazoa. Chromosom. Res. 15, 371-382.

Treaster, S.B., Ridgway, I.D., Richardson, C.A., Gaspar, M.B., Chaudhuri, A.R., Austad, S.N., 2013. Superior proteome stability in the longest lived animal. Age 1-9.

Ujvari, B., Madsen, T., 2009. Short telomeres in hatchling snakes: erythrocyte telomere dynamics and longevity in tropical pythons. PloS ONE 4, e7493.

Ungvari, Z., Csiszar, A., Sosnowska, D., Philipp, E.E., Campbell, C.M., McQuary, P.R., Chow, T.T., Coelho, M., Didier, E.S., Gelino, S., Holmbeck, M.A., Kim, I., Levy, E., Sonntag, W.E., Whitby, P.W., Austad, S.N., Ridgway, I., 2013a. Testing predictions of the oxidative stress hypothesis of aging using a novel invertebrate model of longevity: the giant clam (Tridacna derasa). J. Gerontol. A Biol. Sci. Med. Sci. 68, 359-367.

Ungvari, Z., Ridgway, I., Philipp, E.E.R., Campbell, C.M., McQuary, P., Chow, T., Coelho, M., Didier, E.S., Gelino, S., Holmbeck, M.A., Kim, I., Levy, E., Sosnowska, D., Sonntag, W.E., Austad, S.N., Csiszar, A., 2011. Extreme longevity is associated with increased resistance to oxidative stress in Arctica islandica, the longest-living non-colonial animal. J. Gerontol. A Biol. Sci. Med. Sci. 66A, 741-750.

Ungvari, Z., Sosnowska, D., Mason, J.B., Gruber, H., Lee, S.W., Schwartz, T.S., Brown, M.K., Storm, N.J., Fortney, K., Sowa, J., 2013b. Resistance to genotoxic stresses in Arctica islandica, the longest living noncolonial animal: is extreme longevity associated with a multistress resistance phenotype? J. Gerontol. A Biol. Sci. Med. Sci. 68, 521-529.

Von Zglinicki, T., 2002. Oxidative stress shortens telomeres. Trends Biochem. Sci. 27, 339-344.

Witbaard, R., 1996. Growth variations in Arctica islandica L. (Mollusca): a reflection of hydrography-related food supply. ICES J. Mar. Sci. 53, 981-987.

Witbaard, R., Jenness, M.I., van der Borg, K., Ganssen, G., 1994. Verification of annual growth increments in Arctica islandica L. from the North Sea by means of oxygen and carbon isotopes. Neth. J. Sea Res. 33, 91-101.

Wright, W.E., Shay, J.W., 2005. Telomere biology in aging and cancer. J. Am. Geriatr. Soc. 53, S292-S294.

Zalenskaya, I.A., Zalensky, A.O., 2002. Telomeres in mammalian male germline cells. Int. Rev. Cytol. 218, 37-67. 